\title{
Berichtigung zu Bd. 80, Heft 3/4.
}

In der Arbeit $G$. Santangelo „Über eine neue Ausführungstechnik der Berlinerblau-Reaktion usw." auf Seite 263, Zeile 6 von unten muß es heißen:

„mit destilliertem Wasser mit 0,20 (oder besser 0,40) proz. NaCl-Lösung““ statt:

„mit destilliertem Wasser mit 20 proz. NaCl-Lösung`‘.

\section{Berichtigung zu Bd. 80, Heit 5}

(zur Arbeit: A. Simons, „Kopfhaltung und Muskeltonus. Klinische Beobachtungen" S. 499).

Seite 501, Zeile 20 von unten muß es heißen: „Adduction“ statt „Abduction".

„ 533, Anmerkung 1 muß es heißen: ,als die Drehung“ statt „,als - Drehung".

„547, Zeile 1 von oben sind die Worte: „die wir als Indicator der Kopfwirkung benutzen" zu streichen.

„547, Zeile 15 von oben muß es heißen: ,in der Mitbewegung, im epileptischen Anfall" statt, ,in der Mitbewegung im epileptischen Anfall“".

" 549, Zeile 9 von oben muß es heißen: „Wochenschr. 1919, S. 523“" statt ,Wochenschr. 5, 23, 1919“". 